\title{
Международные организации
}

\section{ОБ ИТОГАХ МЕЖДУНАРОДНОЙ КОНФЕРЕНЦИИ ИМО* ПО СТАНДАРТАМ ОБУЧЕНИЯ, ДИПЛОМИ- РОВАНИЮ И НЕСЕНИЮ ВАХТЫ ПЕРСОНАЛОМ РЫБОЛОВНЫХ СУДОВ}

К.А. Б ек я ш в в*

\section{Цели и задачи конференции}

26 июня -7 июля 1995 г. в Лондоне проходила Мехдународная конференция по подготовке и принятию Международной конвенции по стандартам обучения, дипломированию и несению вахты персоналом рыболовных судов. Созыв этой конференции был обусловлен следующими тремя причинами.

Во-первых, за последние 20 лет значительно изменился состав рыбопромыслового флота: появились суда, оснашенные современным электронным оборудованием, требующим специальных технических знаний у всего экипажа. Если прехде рыбаку для работы на промысловых судах было достаточно окончить трехмесячные курсы, то сейчас он обязан обучаться год и пройти стажировку на радиолокационных тренажерах.

Во-вторых, в связи с созданием совместных предприятий (а их в мире насчитывается более 100 тыс.) для промысла водных биоресурсов возникла потребность (а для некоторых стран и возмож-

* В настоящей статье использованы следующие сокращения: ИМО - Международная морская организация; Конвенция СТКВ 1978 года - Международная конвенция о подготовке и дипломироваяии моряков и несекии вахты 1978 гда; КТС - Комитет полного состава; КМБ - Комитет ИМО по безопасности на море; Конвенция СТКВ (Ф) 1995 года - Международная конвенция по стандартам обучения, диппомированию и несению вахты персоналом рыболовных судов 1995 года.

** Заведуюший кафедрой международного права Московской государствениой юридической академии, доктор юридических наук, професcop, член российской делегации на Международной конференции ИМО (болес полные сведения об авторе см. МЖМП.- 1991.- № 3-4). 
ность) в комплектовании интернациональных экипажей. Кахдый член такого экипаха должен обладать минимальными знаниями и навыками, установленными мехдународно признанными стандартами и правилами.

В-третьих, в последние $15-20$ лет в торговом мореплавании широкое развитие получил финансовый лизинг'. Только Россия по лизингу приобрела около 300 современных морсхих судов. Как правило, эти суда являются собственностью зарубежных офшорных компаний, приписаны $\mathbf{~ и н о с т р а н н ы м ~ п о р т а м ~ и ~ и м е ю т ~ н е р е д х о ~}$ очень неквалифицированный иностранный экипаж. Теперь такой экипах, набираемый, как правило, из граждан развивающихся стран, обязан иметь высокую профессиональную квалификацию, уметь на уровне требований ИМО нести ходовую вахту на мостике.

В-четвертых, в связи с возрастанием числа морских катастроф с промысловыми судами по вине экипажа (по данным ИМО, в 1992 г. было потеряно 245 рыболовных судов, из них кахдое четвертое в результате низкого профессионального уровня әкипажа 2 ) многие государства в законодательном порядке установили высокие стандарты обучения и дипломирования плавсостава промысловых судов, что зачастую вызывает нарекания у професснональных объединений, в том числе мехдународных.

В-пятых, различия в процедуре оформления и выдаче дипломов и подготовке специалистов являются существенной преградой в трудоустройстве рыбаков на суда, плаваюцие под флагом других государств. Проблема может быть решена двумя способами: а) путем заключения конвенции о взаимном признании «рабочих» дипломов; б) принятием международных стандартов и норм по бучению и выдаче таких дипломов.

Вопросы дипломирования плавсостава морских судов в настоящее время регламентируются Международной конвенцией о подготовхе и дипломировании моряков и несении вахты 1978 года $^{3}$ (вступила в силу 28 апреля 1984 г.). Россия как правопреемник СССР участвует в ней с 14 сентября 1979 г. Однако Конвенция СТКВ 1978 года не применяется к морякам, работающим на рыболовных судах (ст. III). Согласно статье IV, под «рыболовным судном» понимается судно, используемое для промысла рыбы, китов, тюленей, моржей или иных живых ресурсов моря. Иными словами, Конвенция СТКВ 1978 года не регламентирует процедуру подготовки рыбаков. Вместе с тем она охватывает вопросы дипломирования и несения вахты моряками, работающими на плавбазах, транспортных рефрижераторах, танкерах и вспомогательных судах.

Учитывая важность подготовки квалифицированного экипажа для всех судов, работающих в системе рыбной промышленности, Правительство СССР в августе 1983 года утвердило Положение о 
3ваниях лиц командного состава морских судов". Этим положением установлена единая процедура выдачи дипломов для экипажей ках торговых, так и рыбопромысловых судов. Общй подход к дипломированию продолжает действовать и в настоящее время, и это бстоятельство содействовало сокрашению холичества аварийных пронсшествий на море.

\section{Вклад ИМО в становление международно-правовых норм по стандартизации обучения и дипломированию персонала рыбаловных судов и несению им вахты}

Как известно, ИМО, начавшая свою работу в 1968 году", является специализированным учреждением ОOH, призванным беспечивать механизм сотрудничества государств в области правительственного регулирования и практики в технических вопросах любого рода, затрагивающих мехдународное торговое судоходство. Она имеет целью также поощрять и содействовать всеобщему принятию практически возможных максимальных мер в вопросах, касающихся безопасности на море, а также рассматривать ауминистративные и правовые вопросы, связанные с проблемами безопасности плавания морских судов (ст. 1 Конвенции $\infty$ ИМО). ЭТа организация, в которую входят 154 государства (в том числе Россия, Азербайдхан, Украина, Эстония, Латвия), выносит рекомендации государствам-членам относительно принятия правил и руководств, касающихся безопасности на море и поправок $\mathrm{K}$ ним (п. «ј» ст. 15 Конвенции 6 ИМО).

Прахтически со дня образования ИМО интенсивно занимается проблемой обеспечения безопасности работы рыболовных судов и их персонала'.

Рамки статьи не позволяют подробно изложить результаты деятельности ИМО в рассматриваемой области. Отмечу лишь, что по вопросам стандартизации обучения и дипломирования персонала рыболовных судов и несения им вахты органами ИМО подготовлено более десяти нормативных актов различной степени полноты и обязательности.

Остановлюсь на некоторых из них, и прехде всего на резолюцияХ Ассамблеи НМО А.539(13) и А.576(14), поскольку они имеют прямое отношение к становлению мехдународных норм и стандартов по дипломированию рыбаков?.

Резолюция А.539(13) утвердила Рекомендации по минимальным требованиям для дипломирования капитанов и вахтенных помощников капитанов рыболовных судов длиной $24 \mu$ и более 8 В этих Рекомендациях под рыболовным судном понимается любое судно, 
используемое на коммерческой основе для промысла рыбы, китов, тюленей, моржей и других живых ресурсов моря. Таким образом, этот документ дословно повторяет определение рыболовного судна, содержащееся в статье IV (h) Конвенции СТКВ 1978 года. Однако, в отличие от Конвенции СТКВ 1978 года, Рекомендации 1983 года распространяются на рыбаков, занятых добычей живых ресурсов моря.

В отличие от Конвенции СТКВ 1978 года резолюция А.539(13) содержит развернутое понятие термина «ограниченные воды»: это такие воды, пределы которых определены Администрацией ${ }^{9}$ и в которых, как предполагается, существует степень безопасности, позволяющая установить стандарты квалификации и дипломирования капитанов и членов экипажей рыболовных судов на более низком уровне по сравнению с тем, который необходим для работы вне этих определенных пределов.

При определении района ограниченных вод Администрация должна принимать во внимание следующие факторы:

1) размеры рыболовных судов, о которых идет речь;

2) расстояние от порта-убежища;

3) наличие радионавигационного оборудования для определения местоположения;

4) наличие в районе плавания спасательных служб и средств связи;

5) наличие служ6, осуществляющих передачу по радио метеорологических сводок;

6) превалирующие погодные условия в данном районе;

7) ограничения, связанные с обледенением;

8) обычные навигационные опасности;

9) интенсивность судоходства.

Соответственно понятие «неограниченные воды» означает воды за пределами ограниченных вод.

Рекомендации содержат пять приложений по минимальным требованиям для дипломирования капитанов (приложение 2) и вахтенных помошников капитанов (приложение 3) рыболовных судов длиной $24 \mu$ и более, плавающих в неограниченных водах, а также по минимальным требованиям для дипломирования капитанов (приложение 4) и вахтенных помощников капитанов (приложение 5) рыболовных судов длиной $24 \mu$ и более, плавающих в ограниченных водах.

Ассамблея ИМО настоятельно призвала правительства государств-членов применять эти рекомендации.

Рекомендации бязывают Администрацию обеспечить, чтобы капитаны и вахтенные помощники капитанов рыболовных судов длиной менее 24 м имели достаточные знания, касаюшиеся без- 
опасности эксплуатации таких судов, имея в виду безопасность всех судов, которые могут плавать в тех же водах, а также необходимость безопасного несения вахты на соответствующих рыболовных судах. Каждый капитан и его вахтенный помошник должны иметь диплом, признаваемый Администрацией, если только Администрация не будет убеждена в том, что ввиду размера рыболовного судна и условий его плавания это будет непрактично или нецелесообразно.

Минимальные требования по дипломированию судовых механиков были закреплены в резолюции Ассамблеи НМО А.623(15), принятой 19 ноября 1987 г. ${ }^{10}$ Эта резолюция утвердила Рекомендацию по минимальным требованиям для дипломирования старших и вторых механиков рыболовных судов с главной энергетической установкой пропульсивной мошностью $750 \mathrm{kBm}$ или более. Она настоятельно призвала правительства стран-членов применять эту рекомендацию.

В соответствии с рекомендациями каждый кандидат на получение диплома должен быть не моложе 18 лет и отвечать требованиям Администрации в отношении состояния здоровья, особенно зрения и слуха. Для получения диплома второго механика претендент должен иметь одобренный стах работы на судне не менее 12 месяцев в составе машинной команды рыболовных судов. Этот период может быть сокращен, но не должен быть менее 6 месяцев, если Администрация потребует от него специальной подготовки, которую считает равноценной одобренному стажу работы на судне, который она заменяет. Для получения диплома старшего механика претендент должен иметь одобренный стаж работы на рыболовных судах не менее 24 месяцев, из которых не менее 12 месяцев - на руководящей должности при наличии диплома второго механика.

В каждом случае одобренный стаж работы на судне может быть заменен одобренным стахем работы на судне в составе машинной команды на торговых судах. Эта оговорка весьма существенна, поскольку во многих странах - в том числе и России - плавсостав часто переходит на работу с торговых судов на рыболовные и наоборот.

В приложении к рекомендации приведены «Минимальные знания, необходимые для получения диплома старшего и второго механиков рыболовных судов с главной энергетической установкой пропульсивной мощностью $750 \mathrm{kBm}$ или более».

Следует отметить также вклад ИМО в становление международных правил, регламентирующих порядок несения вахты на рыболовных судах навигационной и машинной командами. Из многочисленных решений НМО по этому вопросу отметим резолюцию Ассамблеи ИМО А.622(15) «Основные принципы несения ходовой 
машинной вахты на рыболовных судах» от 19 ноября 1987 г." В этом документе термин «вахта» означает либо группу лиц, несущих вахту, либо период ответственности судового механика, в том числе когда его непосредственное присутствие в машинном отделении может и не требоваться. Кахдый вахтенный должен знать свои обязанности по несению вахты. На рыболовном судне каждый вахтенный обязан: а) уметь пользоваться соответствующими системами внутренней связи; б) знать аварийные сигналы, используемые в машинном отделении, и уметь различать их; г) знать расположение и уметь пользоваться противопожарным оборудованием. Перечисляются и другие требования $\mathrm{x}$ несению вахты и должностные обязанности старшего механика судна в вахтенный период.

Основные положения трех указанных резолюций были развиты Документом для руководства по подготовке и дипломированию рыбахов, подготовленным объединенной Рабочей группой ФАО/ИМО/МОТ. Документ состоит из четырех частей и 89 положений, основу которых составили Конвенция МОТ по дипломированию рыбаков 1966 года, глава V СОЛАС-74, Заключительный акт Международной конференции по безопасности рыболовных судов 1977 года и ряд рекомендаций ИМО и МОТ. Документ регулирует вопросы обучения и дипломирования персонала как судов длиной 24 м и более, так и малотоннажных судов. В нем содержатся стандарты и программы по обучению, требования $\mathbf{K}$ персоналу, занимающемуся подготовкой рыбаков, рекомендации относительно организации курсов (краткосрочных и долгосрочных). Значительное внимание уделено методологии обучения и вопросам экзаменовки обучаемых лиц ${ }^{12}$.

Ассамблея ИМО в резолюции А.646, принятой на 16-й сессии в октябре 1989 года, отметила, что «имеющиеся статистические данные показывают, что количество аварий и несчастных случаев на работе среди рыбаков значительно превышает соответствуюшие показатели среди других моряков» ${ }^{13}$. Ассамблея признала, что для повышения безопасности рыбаков на море должно быть уделено соответствующее внимание установлению стандартов, относящихся не только к судам, условиям работы и оборудованию, но также к подготовке рыбаков, поскольку рыболовные суда эксплуатируются в экономических зонах, простираюшихся далеко в международные воды, и связанную с ними глубоководную морскую среду. Ассамблея призвала КБМ рассмотреть статистику аварий рыболовных судов и несчастных случаев с рыбаками как вопрос первоочередной важности, для того чтобы разработать в последующем соответствуюшие поправки к конвенциям и кодексам для повышения безопасности рыбаков на море. Наконец, она уполномочила КБМ рассмотреть поправку к Конвенции СТКВ 1978 года, касаю- 
щуюся подготовки и дипломирования экипажей рыболовных судов с учетом ранее принятых Ассамблеей резолюций (среди них «Основные принципы несения ходовой навигационной вахты на рыболовных судах»14, «Дипломирование капитанов и вахтенных помошников капитанов рыболовных судов длиной 24 метра и более»'s, «Требования $\mathrm{x}$ подготовке капитанов рыболовных судов длиной менее 24 метров, работающих в неограниченных и ограниченных водах» и «Документ для руководства по подготовке и дипломированию рыбаков», изданный ФАО, МОТ и ИМО в 1988 г.)

Согласно резолюции А.779(18), принятой 18-й Ассамблеей ИМО 4 ноября 1993 г., и Долгосрочному плану работы, одобренному на 65-й сессии КБМ, на Комитет возлагалась обязанность до 2002 года и далее заниматься вопросами подготовки персонала, несения им вахты, в частности разрабатывать служебные инструкции для морского персонала, включая моряков, рыбаков, морских лоцманов, операторов СДС, лиц, ответственных на морских плавучих установках за безопасность на море, а такхе персонала, работающего в порту16.

\section{Работа конференцин и ее итоги}

- В соответствии с первоначальным мандатом Комитет по безопасности на море интенсивно работал над поправками к Конвенции СТКВ 1978 года, связанными с подготовкой и дипломированием экипажей рыболовных судов, принимая во внимание ранее принятые резолюции ИМО и Документ для руководства по подготовке и дипломированию рыбаков. Впоследствии государствачлены ИМО сочли целесообразным внести в Конвенцию СТКВ 1978 года соответствуюшие изменения и дополнения относительно дипломирования моряков, а по вопросам дипломирования рыбаков разработать специальную конвенцию ${ }^{17}$.

Проект этой конвенции и лег в основу работы открывшейся согласно решению совета ИМО 26 июня 1995 г. конференции (завершила работу 7 июля 1995 г.). Обрашаясь к участникам конференции, генеральный сехретарь ИМО г-н У.А.О'Нил сказал: «Ваше присутствие убеждает в том, какое большое внимание вы придаете самой конференции и насколько международное морское сообщество озабочено проблемами обеспечения безопасности рыбаков» ${ }^{18}$. У.А.О'Нил подчеркнул также, что рыболовство является древнейшей индустрией со своими традициями. Коренная модернизация этой отрасли, сушественный разрыв между прибрежным и дистанционным флотом настоятельно требуют разработки общепризнанных норм и правил по стандартизации подготовки, дипломирова- 
нию персонала рыболовных судов и несению им вахты. Обеспечение безопасной жизни рыбаков должно стать главным в разрабатываемых конференциями правилах.

В конференции приняли участие примерно 100 стран и наблюдатели от 20 международных организаций. Российскую делегацию возглавлял начальник управления мореплавания Роскомрыболовства капитан, дальнего плавания А.А.Козлов. Конференция под аплодисменты избрала своим председателем известного юриста-мариниста, профессора Г.Г.Иванова, постоянного представителя России в ИМО, а председателем Комитета полного состава (главного рабочего органа) - представителя Японии Е.Сасамуру, опытного судостроителя и дипломата, проработавшего не один десяток гет в аппарате ИМО.

Как уже отмечалось, основными документами для обсуждения на заседаниях Комитета полного состава были проект Международной конвенции по стандартам обучения, дипломированию персонала рыболовных судов и несению им вахты (подготовлен ИМО) и документ с аналогичным названием, разработанный Межсессионной рабочей группой. В ходе конференции был представлен солидный пакет дополнений и предложений, которые были тшательно рассмотрены на специальных рабочих группах и на сессии $\mathrm{KAC}$, и многие из них были приняты.

Как и ожидалось, на заседании КПС развернулась дискуссия по вопросам применения и вступления в силу Конвенции СТKB( осуществления контроля. Рабочая группа, заседавшая до начала конференции, рекомендовала в статью 3 (Применение конвенции) включить дополнительный пункт о том, что положения Конвенции не применяются к персоналу судов, используемых для: а) спорта; б) обработки рыбы или друтих живых ресурсов моря; в) исследования и обучения; или г) перевозки рыбы (по аналогии со ст. 3 Торремолиносского протокола 1992 г. и ст. III Конвенции СТКВ 1978 г.). Однако большинство государств не согласились с этим предложением на том основанин, что в проекте конвенции дано четкое определение рыболовного судна: таковым является любое судно, используемое на коммерческой основе для промысла рыбы или иных живых ресурсов моря. Таким образом, конвенция будет регламентировать вопросы подготовки и дипломирования персонала только добываюших судов длиной $24 \boldsymbol{\mu}$ и более. К сожалению, это определение вывело из-под юрисдикции конвенции плавбазы и суда, перевозящие рыбопродукцию, а также вспомогательный флот.

По этой причине российская делегация внесла для обсуждения следующее предложение: «Стороны, чьи морские суда длиной 60 метров и более и/или пропульсивной мощностью двигателя более $3000 \mathrm{kBm}$ должны устанавливать дополнительные требования для 
таких судов в части стандартов обучения и дипломирования персонала таких судов и несения им вахты».

В ходе обсуждения этого предложения ряд стран (Дания, Нидерланды, Великобритания и др.) поддержали его, а некоторые (Япония, Китай и другие азиатские страны) решительно не согласились с ним. В результате Председатель КАС предложил передать российское предложение на проработку в Рабочую группу. На заседании Рабочей группы Е.Сасамура предложил для обсуждения следующее предложение: «Персонал, работающий на борту рыболовных судов длиной $\{60\}$ метров и более или пропульсивной мошностью $\{3000\} \kappa \mathrm{Bm}$ и более, хоторые обрабатывают на борту таких судов уловы рыбы, будет дипломироваться в соответствии с Конвенцией СТКВ 1978 года». Российская делегация возражала против предложенного варианта текста статьи, поскольку упомянутая конвенция никакого отношения к рыболовным судам не имеет, хотя и признала, что националыные стандарты не должны быть ниже стандартов, установленных Конвенцией СТКВ 1978 года.

В результате Рабочая группа постановила на базе российских предложений подготовить резолюцию конференции, в которой отразить три принципиальных момента:

1) будущая конвенция не будет охватывать процессоры и суда, перевозяцие рыбопродукцию;

2) предложить КБМ ИМО разработать в кратчайший срок требования по дипломированию экипажей таких судов;

3) предложить правительствам внести в свои правила стандарты подготовки персонала таких судов на уровне требований Конвенции СТКВ 1978 года с поправками 1995 года. Эта резолюция была утверждена конференцией.

Вторая проблема, вызвавшая дискуссию, касалась процедуры вступления конвенции в силу. Проект конвенции гласил: «Конвенция встугает в силу по истечении $\{12\}$ месяцев с даты, в хоторую не менее $\{15\}$ государств либо подпишут ее без оговорки о ратификации, принятии или утверждении, либо сдадут на хранение соответствующие документы о ратификации, принятии, утверждении или присоединении в соответствии со статьей 10 Конвенции». Против этой формулировки выступили делегации Китая, Гонконга, Японии, Индонезии и других стран, предложившие увязать условия вступления конвенции в силу с тоннажем судов. Теоретически конвенция может быть довольно быстро подписана 15 государствами, но последние будут обладать небольшим общим тоннажем судов. По мнению этих стран, конвенция должна вступить в силу только после принятия ее государствами, собша обладающими как минимум 50\% мирового тоннажа рыболовных судов. 
Против этого предложения выступила делегация РФ, выдвинувшая следуюшие аргументы: во-первых, мировое сообшество впервые стремится закрепить в международном договоре унифицированные стандарты по подготовке и дипломированию рыбахов, и если в нее будут включены оговорки о тоннаже, то вступление хонвенции в силу задержится на многие годы, как это имеет место с Торремолиносской конвенцией 1977-1993 годов ${ }^{19}$; во-вторых, если конвенция вступит в силу в достаточно короткий срок, то этот факт станет своеобразным стимулом для присоединения $\mathrm{K}$ ней наибольшего числа стран, и тем самым конвенция станет авторитетным международным документом. Российская делегация предложила утвердить соответствуюшую статью без изменений. Предложение делегации РФ и ее аргументы поддержали делегации Канады, Дании, Аргентины, Норвегии, Исландии, Великобритании, Бразилии, Перу и других стран. В результате КАС оставил статью 12 проекта хонвенции без изменений ${ }^{20}$.

Довольно острую дискуссию вызвала и проблема контроля.

Проект конвенции (ст. 7) предусматривал следующий порядок контроля. Морские рыболовные суда при нахохдении в портах участника конвенции подвергаются контролю, осушествляемому должностными лицами, надлежащим образом уполномоченными этим участником с целью проверки того, что все работающие на них лица, которые согласно конвенции должны быть владельцами дипломов, имеют также дипломы или соответствуюшие льготные разрешения. Такие дипломы должны признаваться, если нет очевидных оснований полагать, что диплом был получен незаконным путем или что владелец диплома не является тем лицом, которому он был первоначально выдан.

В случае ळбаружения какого-либо нарушения осуществляюее контроль должностное лицо немедленно уведомляет в письменном виде хапитана судна и консула или, если консула не имеется, ближайшего дипломатического представителя либо морские власти государства, под флагом которого судно имеет право плавания, для принятия соответствующих мер.

Если при осушествлении контроля не устранены недочеты и установлено, что с учетом размера и типа судна, протяженности и характера его рейса создается опасность для людей, имущества или окружающей среды, осуществляющее контроль государство піринимает меры, чтобы судно не вышло в море до тех пор, пока эти требования не будут выполнены настолько, чтобы считать такую опасность устраненной. О фактах, касающихся принятых мер, немедленно сообшается генеральному секретарю ИМО.

При осуществлении контроля принимаются все возможные меры, чтобы избехать необоснованного задержания или необосно- 
ванной отсрочки отхода судна. Если судно необоснованно задерхано или его отход необоснованно отсрочен, оно имеет право на компенсацию понесенных в связи с этим убытков или ущерба.

Межсессионная Рабочая группа разработала два варианта статьи о контроле. Во-первых, дала свою редакцию приведенного текста проекта статьи 7 конвенции и, во-вторых, выработала новый текст следующего содержания: «Рыболовные суда при нахождении в порту другой Стороны подвергаются контролю, осушествляемому должностными лицами, надлежашим ббразом уполномоченными этой Стороной с целью проверки того, что все работающие на них лица, которые по Конвенции должны быть владельцами дипломов, имеют тахие дипломы или соответствующие льготные разрешения».

Результаты длительного обсуждения трех текстов выявили следующие позиции участнихов конференции: Аргентина, Куба, Вануату, Перу, Чили, Марокко, Соломоновы Острова и др. предложили одобрить статью 7 проекта конвенции без изменений; Российская Федерация, Корея, Норвегия, Бельгия, Нидерланды и др. высказались за развернутый текст Рабочей группы; Австралия, Болгария, Филиппины - 32 второй (укороченный) вариант статьи 7 с переносом остальных вопросов в прнложение х конвенции.

Взаимосогласованный текст* был выработан в рамках Рабочей группы и лег в основу будущей статьи 8 конвенции и правила 4 приложения.

\section{Основные положения Конвенции 1995 года}

Общие обязательства участников по эффективному применению положений конвенции и приложений к ней содерхатся в статье 2.

Статья 2 содержит определения ключевых терминов, применяемых в конвенции. В частности, термин «Администрация» означает правительство государства, под флагом которого судно имеет право плавания. Под термином «диплом» понимается действительный документ, как бы он ни назывался, выданный или признаваемый в соответствии с Конвенцией 1995 года и дающий право его владельцу на занятие должности, указанной в этом документе или разрешенной национальными правилами.

Согласно статъе 3, конвенция применяется к персоналу, занятому в эксплуатации морских рыболовных судов, имеюших право плавания под флагом государства-участника. Под «морским рыболовным судном» понимается рыболовное судно иное, чем то, кото-

* См. следующй̆ раздел статъи. 
рое плавает исключительно во внутренних водах, в пределах зашишенных вод и в непосредственной $\mathrm{K}$ ним близости либо в районах действия портовых правил.

Одно из важных обязательств государств-участников - содействие техническому сотрудничеству (ст. 9). Стороны конвенции по консультации с генеральным секретарем ИМО и при содействии ИМО оказывают поддержку тем государствам-участникам, которые обращаются с просьбой об оказании такой помощи. Конвенция определяет примерные области (проблемы) такого сотрудничества:

a) обучение административного и технического персонала;

б) учреждение учебных заведений для подготовки персонала рыболовных судов;

в) оснащение оборудованием и пособиями учебных заведений;

г) разработка соответствуюших программ подготовки, включая прохождение практики на морских рыболовных судах. Стороны могут сотрудничать и по другим аспектам подготовки персонала рыболовных судов, а ИМО в сотрудничестве с ФАО и МОТ будет продолжать прилагать усилия по стимулированию сотрудничества в технической и образовательной областях.

Заключительные разделы конвенции посвящены процедуре внесения поправок. На конференции этот важный вопрос практически не обсуждался, поскольку еще в 70-х годах после длительных дебатов в органах МMO $22^{22}$ было решено, что в конвенции, разрабатываемые в рамках этой организации, следует включать стандартную статью о процедуре молчаливого принятия поправок.

Сушность процедуры вкратце заключается в следующем. Любое государство-участник представляет генеральному секретарю ИМО предложение о внесении соответствуюшей поправки в конвенцию. Затем это предложение рассылается всем государствам, являюшимся участниками конвенции. Одновременно проект поправки передается на рассмотрение в КБМ ИМО. В обсуждении проекта поправки участвуют все стороны конвенции (вне зависимости от членства в ИМО). Поправка одобряется или отклоняется большинством в $2 / 3$ сторон, присутствующих и голосующих -на заседании КБМ. Одобренная поправка направляется государствам - участникам конвенции и вступает в силу только после одобрения ее $2 / 3$ сторон. С этого момента она становится обязательной уже для всех государств, участвуюших в данной конвенции.

Процедура молчаливого принятия может быть применена и в иной ситуации. В частности, она предусмотрена в пункте 3 статьи 10 Конвенции 1995 года. По просьбе любой стороны, поддержанной не менее чем $1 / 3$ сторон, ИМО после консультации с МОТ и ФАО созывает конференцию участников конвенции для рассмотрения проекта поправок. После принятия поправки $2 / 3$ голосов она на- 
правляется для одобрения государствам и вступает в силу после одобрения $2 \%$ государств.

Конвенция открыта для подписания с 1 января 1996 г. по 30 сентября 1998 г. в штаб-квартире ИМО. Она вступает в силу по истечении 12 месяцев с даты, в которую не менее 15 государств либо подпишут ее без оговорки о ратификации, принятии или утверждении, либо сдадут на хранение соответствующие документы о ратификации, принятии, утверждении или присоединении.

Процедурные вопросы подготовки и дипломирования персонала рыболовных судов и несения им вахты детально решены в приложении к конвенции, которое имеет такую же юридическую силу, как и положения самой конвенции. Основополагающей является глава II, регламентирующая порядок дипломирования капитанов, лиц командного состава, механиков и радиооператоров.

Согласно приложению, кахдый капитан рыболовного судна длиной 24 м и более, эксплуатирующегося в неограниченных (unlimited) водах, должен иметь соответствующий диплом. Кандидат на получение диплома должен отвечать требованиям государства-участника в отношении состояния здоровья, особенно зрения и слуха. Он должен также отвечать требованиям, предъявляемым $\mathbf{K}$ дипломированному вахтенному помощнику капитана на рыболовных судах длиной $24 \boldsymbol{\mu}$ и более и иметь одобренный стаж работы на судне не менее 12 месяцев в качестве вахтенного помощника капитана или капитана рыболовных судов длиной не менее 12 м. Однако вместо этого Администрация может допускать одобренный стаж работы в качестве вахтенного помощника капитана морских судов, на которые распространяется Конвенция 1978 года.

Наконец, претендент на получение диплома капитана обязан сдать экзамен или экзамены для оценки профпригодности в соответствии с национальньми требованиями государства - участника Конвенции 1995 года.

В дополнении к главе 2 содержатся «Минимальные знания, необходимые для получения диплома капитана рыболовных судов длиной $24 \boldsymbol{м}$ и более, эксплуатируюшихся в неограниченных водах». В число обязательных требований включено и знание узловых вопросов морского права. В частности, претендент обязан знать свои обязанности, вытекающие из международных свидетельств и иных документов, наличие которых на рыболовных судах предусмотрено международными конвенциями, порядок их получения и срок действия. Он должен досконально знать обязанности, вытекающие из Протокола БРС-93 г., главы V СОЛАС-74 г., приложения I и V к МАРРОЛ-73/78 гт. морских санитарных деклараций и правил, МППСС-72 г. и других мехдународных документсв, касающихся обеспечения безопасности судна и экипажа. 
Правило П/2 содержит обязательные минимальные требования для дипломирования вахтенных помощников капитанов рыболовных судов длиной 24 н и более, которые эксплуатируются в неограниченных водах.

Каждый вахтенный помощник обязан иметь соответствующий диплом. Претендент на получение такого диплома должен:

a) быть не моложе 18 лет;

б) отвечать требованиям стороны в отношении состояния здоровья, особснно зрения и слуха;

в) иметь одобренный стах работы на рыболовных судах в составе палубной хоманды не менее двух лет;

г) иметь одобренный стаж работы, подтверждающийся в соответствии с Конвенцией 1978 года.

Дополнение к правилу П/2 - «Минимальные знания, необходимые для получения диплома вахтенного помощника капитана рыболовных судов длиной 24 и более, эксплуатирующихся в неограниченных водах". Конвенция регламентирует также порядок дипломирования хапитанов рыболовных судов длиной 24 м и более, эксплуатируюшихся в ограниченных водах. Согласно правилу П/3, кандидат на получение диплома должен отвечать требованиям государства-участника в отношении состояния здоровья, особенно зрения и слуха. Кроме того, кандидат также обязан отвечать требованиям для дипломирования вахтенного помощника капитана рыболовных судов длиной 24 м и более, эксплуатирующихся в ограниченных водах, и иметь одобренный стаж работы в качестве вахтенного помощника капитана или капитана рыболовных судов длиной не менее $12 \mathrm{M}$.

Дополнение к правилу П/3 содержит «Минимальные знания, необходимые для получения диплома капитана рыболовных судов длиной $24 \mu$ и более, эксплуатирующихся в ограниченных водах».

На конференции консенсусом одобрено девять резолюций ${ }^{23}$ : Подготовка радиоспециалистов для Глобальной оперативной системы связи при бедствии и для обеспечсния безопасности (№ 1); Подготовка с помощью радиолокационного тренажера (№ 2); Подготовка и рекомендации для персонала рыболовных судов (№ 3); Подготовка палубных матросов рыболовных судов длиной 24 м и более (№ 4); Подготовка персонала рыболовных судов в отношении способов личного выживания (№ 5); Подготовка и дипломирование персонала крупных рыболовных судов (№ 6); Содействне участию женщин в рыбной промышленности (№ 8); Взаимоотношения мехду людьми на борту судов (№ 9) и др.

Конвенция содержит ряд положений о механизме обеспечения ее применения.

Проблема инфорсмента является одной из ключевых в международном праве ${ }^{24}$. Средствами обеспечения выполнения международ- 
но-правовых норм, в том числе в отношениях, регулируемых морским правом ${ }^{25}$, служат контроль, наблюдение, мониторинг, отчетность, санкции и т.д.

На наш взгляд, институт инфорсмента имеет особое значение для реализации конвенций ИМО, предметом правового регулирования которых являются обеспечение безопасности мореплавания и прежде всего охрана человеческой жизни на море. С сожалением приходится констатировать, что количество аварий в мировом судоходстве не уменьшается. Например, в 1994 году были потеряны 103 судна, погибли 1,5 тыс. человек ${ }^{26}$.

Поэтому в последние годы КБМ ИМО тщательно исследует проблему повышения эффективности конвенций. кодексов и руководств, принятых Ассамблеей этой организации. Речь идет об обязательности этих международных документов для всех государств, суда которых занимаются коммерческой деятельностью в Мировом океане. На 65-й сессии КБМ ИМО было констатировано, что на февраль 1995 года по 20 конвенциям ИМО было всего 796 ратификаций ${ }^{27}$. Еще хухе обстоит дело с кодексами ИМО: всего два государства добровольно применяют Кодекс по остойчивости рыболовных судов и Документ ФАО/МОТ/КМО по подготовке рыбаков ${ }^{28}$.

Учитывая актуальность проблемы эффективности применения норм Конвенции по дипломированию рыбаков, особенно ее приложений, участники конференции уделяли достаточно большое внимание проблемам инфорсмента. Конвенция и ее приложения содержат большой набор средств обеспечения выполнения норм и правил по дипломированию рыбаков и несению ими вахты. Отметим некоторые из них.

1. Статья 1 конвенции ббязывает стороны осуществлять положения конвенции и приложений $\mathbf{k}$ ней. В этих целях Стороны обязуются издавать все необходимые законы, декреты, приказы и правила и принимать все другие меры, которые могут потребоваться для полного осуществления положений конвенции в целях обеспечения охраны человеческой жизни и защиты морской среды.

2. В соответствии со статьей 3 конвенции каждая сторона должна представлять генеральному секретарю следуюшую информацию:

a) доклад о мерах, которые она приняла для полного осушествления полохений хонвенции;

б) достаточное количество образцов дипломов, выдаваемых в соответствии с конвенцией;

в) любую информацию о выполнении положений конвенции.

Тем самым эта статья закрепила одну из распространенных форм контроля - обязательную регулярную отчетность государств.

3. В отличие от Конвенции 1978 года, Конвенция 1995 года содерхит развернутые положения о контроле. При обсуждении на 
конференции этой проблемы российская делегация, учитывая важность этого эффективного средства, настаивала на разработке всеобъемлющего положения, содержащего не только материальные, но и процессуальные нормы. Во многом благодаря такой позиции в статью 8 конвенции вошло достаточно емкое понятие контроля и средств его осуществления. Согласно пункту 1 статьи 8, морские рыболовные суда при нахождении в порту другой Стороны подвергаются контролю специально уполномоченных лиц. Цель такого контроля - проверить, что все работающие на судне лица имеют соответствуюшие дипломы или льготные разрешения. В случае бнаружения нарушений уполномоченное лицо немедленно уведомляет в письменном виде капитана и консула страны флага судна либо морские власти государства, под флагом хоторого плавает такое судно. Осуществляюшая контроль сторона вправе не разрешить судну выход в море, если не будут устранены недостатки, создающие опасность для здоровья людей или чистоты охружающей среды. При осушествлении контроля следует принимать все возможные меры, чтобы избежать необоснованного задержания или необоснованной отсрочки отхода судна. Если судно необоснованно задержано или его отход необоснованно отсрочен, оно имеет право на компенсацию понесенных в связи с этим любых убытков или ущерба. Наконец, в процессе контроля к иностранным рыбакам не должны применяться более высокие требования, нежели к экипажу судов, плавающих под флагом государства порта.

Положения статьи 8 конвенции раскрыты в правиле 4 приложения. В нем излагаются цели и объект контроля, в частности проверка того, что экипаж судна должен иметь соответствующие дипломы или льготные разрешения. Уполномоченное лицо вправе оценить способность персонала судна соблюдать предписываемый конвенцией порядок несения вахты. Оно также вправе устаногить, не имело ли судно столкновения, посадки на мель или касания грунта, а также не допустило ли оно сброса вредных веществ.

В этом правиле перечисляются те недочеты, которые могут считаться создающими опасность для людей, судна, его имущества или окружающей морской среды. Таковыми являются:

a) отсутствие у лиц, которые должны обладать дипломами, соответствующих дипломов или льготных разрешений;

б) невыполнение судном предписанных Алминистрацией требований, касающихся несения ходовой навигационной или машинной вахты;

в) отсутствие в составе вахты квалифицированного лица по обслуживанию оборудования и приборов, обеспечивающих безопасное плавание, радиосвязи для целей безопасности или предотвращения загрязнения; 
г) отсутствие возможности обеспечить отдохнувшим составом первую вахту при отходе в рейс и последующие сменяющие вахты.

Государство-участник вправе не выпускать судно, если не были приняты меры, касающиеся устранения упомянутых выше недостатков, если осуществляющее контроль государство установило, что обнаруженные недостатки создают опасность для людей, имущества или окружающей среды.

Таким образом, можно констатировать, что Конвенция 1995 года содержит достаточный перечень средств обеспечения выполнения международных правил и норм по дипломированию рыбаков и несению ими вахты.

\section{Проблемы имплементации Конвенции 1995 года в России}

. Впервые международное сообщество получило свод самостоятельных правил, регламентирующих обучение и подготовку рыбаков, их дипломирование и организацию несения вахтенной службы на рыболовных судах с учетом специфики такого рода деятельности.

Действуюшая в настояшее время в России система подготовки (обучения) персонала, дипломирования и организации несения вахты на судах едина как для торгового, так и для всех видов промыслово-производственных флотов и базируется на нормативно-правовой базе торгового флота. Эта система недостаточно учитывает специфику работы судов рыбопромысловой отрасли, и - как следствие подготовка, дипломирование и организация несения вахты требуют коренного пересмотра. Кроме того, действуюшая система подготовки кадров для флота является громоздкой и дорогостоящей, исходит из приоритетов торгового флота и соответственно органа, ведающего транспортом, - Министерства транспорта России.

Конвенция 1995 года позволит создать новую, независимую систему подготовки, дипломирования и организации несения вахты на рыболовном флоте, максимально учитываюшую специфику его промысловой работы.

Конвенция предусматривает двухступенчатую систему подготовки комплавсостава. На первой ступени предусмотрена подготовка вахтенных помощников и вахтенных механиков с выдачей соответствующего диплома (при наличии стажа работы на рыболовном судне). На второй ступени предусмотрена подготовка капитанов и старших механиков из лиц, имеющих дипломы вахтенного механика и соответствующий практический стаж работы в должности штурмана или механика на рыболовном флоте. 
Такая система не только улучшит практическую подготовку специалистов руководящего звена рыбопромыслового флота, но и позволи отобрать в это руководящее звено специалистов, обладающих неббходимыми качествами для полноценного руководства судовыми коллективами и решения стояших перед ними промысловых задач.

Конвенция 1995 года несомненно отвечает как текущим, так и долговременным интересам России.

С целью практической реализации конвенции представляется необходимым:

1. Провести организационную и аналитическую работу для получения полномочий Правительства Российской Федерации, с тем чтобы хонвенция была подписана и ратифицирована Россией в кратчайший срок.

2. Разработать проект нового Положения о дипломировании персонала рыбопромысловых судов, с тем чтобы сразу после вступления Конвенции 1995 года в силу представить его на утверждение в Правительство Российской Федерации.

3. Пересмотреть действуюшие и разработатъ новые программы подтотовки (буучния) и переподготовки командного состава рыбопромыслового флота, исходя из требований конвенции и упомянутого Положения о дипломировании персонала рыбопромысловых судов.

4. Разработать План мероприятий по переходу на новую систему подготовки (ббучения), дипломирования и несения вахты на рыбопромысловом флоте России.

' См. Бекапев К.А. И все-таки лизинг//Рыбацкие новости. - 1995. № 3-4; Офшорные хомпании: обзојы, хомментарии, рекомендации. M., 1995.

${ }^{2}$ Cм. Doc. FSI 3/5/2. - 21 Dec. 1995. - Annex 1. Краткое описание этих случаев см.: Doc. FSI 3/INF. - 8, 25 Nov. 1994.

${ }^{3}$ Подробнее о хонвенции см. Иванов Г.Г. Международная морская органи зация. - М., 1994.- С. 121-131; Рудаков В. Вступила в силу Международная хонвенция 1978 г. о подготовке и дипломировании моряхов и несении вахты//Морской флот. - 1985. - № 3. -C. 29-32; STCN Convebtion to inter into force in April 28. 1984//Shipping World and Shipbuilder. - 1983. - June. - P. 311-312.

${ }^{4}$ См. СП СССР. - 1983. - № 26. - С. 150.

s Пб истории создания ИМО см. Бекяшев К.А., Серебряхов В.В. Международные морские организация. - Л., 1978; Бекпшев К.А., Серебраков В.В. и др. Международные транспортные организации. - М., 1986; Иванов ГГ. Международная морская организация. - М., 1994. - С. 6-12.

- См. Бекяпев К.А., Клетной В.Н. Международная морская организация.- Кн. 1. - М., 1988. - C. 87-100; Mankabady S. International Maritime Organization. - Vol. 1-2. - L., 1986. - P. 200-218. 
7 IMI Assembly. Fourteenth session. 11-22 Nov. 1985//Resolutions and others decisions. - L., 1986. - P. 111-112.

- Историю разработки этих правит подробнее см. Бехяшев КА. Международные правила по подготовке и днпломированию рыбахов//Безопасность мореплавания и ведения промысла. - Вьп. 75. - Л., 1985. C. 34-38.

9 Адмннистрация - правительство или уполномоченньй им орган.

10 Texct cm. OMI Asseblec. Quinzier.e session. 9-20 Nov. 1987//Resolutions et autres decisions. - L., 1988. - P. 141-144.

11 Текст см. Ibid. - P. 137-141.

$12 \mathrm{CM}$. Document for guidance on fishermens training and certification. An international maritime training guide. - L., 1988.

${ }_{13}$ IMO. Assembly. Sixteenth session. 9-20 October 1989//Resolutions and other decisions. - L., 1990. - Res. A.646 (16). - P. 33-34.

14 IMO. Assembly. Twelfth session. 9-20 November 1981//Resolutions and other decisions. - L., 1982. - Res. A.483(12). - P. 195-198.

is IMO. Assembly. Thirteenth session. 7-18 November 1983//Resolutions and other decisions. - L., 1984. - Res. A.539(13). - P.212-231.

$16 \mathrm{CM}$. Long-termwork plan \{up to 2002\}. - Doc. MSC/65/22/3. 9 May 1995. - Annex.

17 Подробнее о ходе разработки проехта хонвенции и приложений $\mathbf{k}$ нему см. Report of the Maritime Safety Committee on its sixty-fourth session. Doc. MSC/64/22/Add.1,5. - Jan., 1995. - P. 4-6; Training and Watchkeeping. - Doc. MSC.64/8/1. - 4 Oct. 1994.

is Doc. STCW-F/CONF/INF.2. - 26 June 1995. - P. 1.

19 Тор́ремолиноссхая Международная хонвенция по безопасности рыболовных судов была одобрена 2 апреля 1977 г. В статье 10 этой конвениии сказано, что она вступает в силу по истечении 12 месяцев с даты, на которую не менее 15 государств, рыболовный флот которых в совокупности составляет не менее 50\% ৩бщей численности мирового рыбопромыслового флота, подпишут конвенцию без оговорох о ратификации. Конвенцию подписали 14 государств. Россия участнихом конвенции не является. В апреле 1993 года на международной конференции был одобрен Торремолиносский протокол к Конвенции 1977 года, статья 10 которого гласит, что он вступает в силу через 12 месяцев после даты, на которую не менее 15 государств, рыболовньй флот которых в совокупности имеет не менес 14 тыс. судов длиной $24 \mu$ и болес, либо подписали его без оговорки относительно ратифихации, принятия или утверждения, либо сдали на хранение необходимые ратификационные грамоты, документы о принятии, утверждекии или присоединения в период с 1 июня 1993 г. по 30 июня 1994 r.

На 1 июля 1995 г. Протокол ратифицировали всего два государства (тексты протохола и хонвенции см. 1993 Torremolinos Protokol and Torremolinos International Convention for the Safety of Fishing Vessels// Consolidated edition. - L., 1995).

20 См. Doc. STCW-F/CONF/CW/RD/2. - 29 June 1995.

21 Tекст хонвенции см. Doc. STCW-F/CONF/DC/1. - 5 July 1995. P. $1-54$.

22 См. подробнес Маковский АЛ., Бекпшев К.А. О процедуре изменения хонвенции ИМКО по техническим вопросам морсхопо судоходства// 
Проблемы морского права и международного торгового мореплавания. 1975. - Вып. 38(44). - С. 73-93.

${ }_{23}$ Текст резолюций см. Doc. STCW-F/CONF/DC/2. - 5 July 1995. P. $1-15$.

$24 \mathrm{CM}$ ЛГУ, 1966. - С. 183 и далее.

25 См. Бекапев К.А., Сапронов В.Д. Мировое рыболовство: вопросы международного сотрудничества. - М., 1990. - С. 123-170.

26 См. Яшин С. Бедственный год для мирового судоходства//ПанораMa. - 1995. - № 27-28.

27 См. Doc. MSC 65/19/1. - 9 March 1995. - P. 1.

28 CM. Doc. MSC 65/19/1. - Annex. - 10 March 1995.

Cтатьr поступила в редакцию в октrбре 1995 года. 